This is the final peer-reviewed accepted manuscript of

CORRADINI, CARLO; SPALLETTA, CLAUDIA; MOSSONI, ANGELO; MATYJA, HANNA; OVER, D. JEFFREY:

Conodonts across the Devonian/Carboniferous boundary: a review and implication for the redefinition of the boundary and a proposal for an updated conodont zonation. GEOLOGICAL MAGAZINE 154. ISSN 00167568

DOI: $10.1017 / S 001675681600039 X$

The final published version is available online at:

http://dx.doi.org/10.1017/S001675681600039x

Rights / License:The terms and conditions for the reuse of this version of the manuscript are specified in the publishing policy. For all terms of use and more information see the publisher's website.

This item was downloaded from IRIS Università di Bologna (https://cris.unibo.it/)

When citing, please refer to the published version. 


\title{
Conodonts across the Devonian/Carboniferous boundary: a review and implication for the redefinition of the boundary and a proposal for an updated conodont zonation
}

\author{
CARLO CORRADINI*†, CLAUDIA SPALLETTA $\ddagger$, ANGELO MOSSONI*, \\ HANNA MATYJA $\& \&$ D. JEFFREY OVER
}

\author{
* Dipartimento di Scienze Chimiche e Geologiche, Università di Cagliari, via Trentino 51, I-09129 Cagliari, Italy \\ $\ddagger$ Dipartimento di Scienze Biologiche, Geologiche e Ambientali, Alma Mater Studiorum Università di Bologna, via \\ Zamboni 67, I-40126 Bologna, Italy \\ $\S$ Polish Geological Institute - National Research Institute, Rakowiecka 4, PL-00-975 Warsaw, Poland \\ IDepartment of Geological Sciences, State University of New York College at Geneseo, Geneseo, NY 14454, USA
}

\begin{abstract}
This paper is a contribution to the redefinition of the base of Carboniferous system. At present the criterion for the definition of the Devonian-Carboniferous boundary is the first occurrence of a conodont species. In order to evaluate the stratigraphic potential for new criteria for the definition of the Devonian-Carboniferous boundary, the distribution of conodont species of Bispathodus, Branmehla, Palmatolepis, Polygnathus, Protognathodus, Pseudopolygnathus and Siphonodella across the boundary is presented and discussed. An updated biozonation scheme across the boundary based on the First Appearance of Bispathodus ac. aculeatus, Bispathodus costatus, Bispathodus ultimus, Protognathodus kockeli, Siphonodella bransoni and Siphonodella duplicata is proposed, and it is suggested that the new criterion for the definition of the base of the Carboniferous system be the First Appearance Datum of Pr. kockeli or Si. bransoni.
\end{abstract}

Keywords: conodonts, Devonian-Carboniferous boundary, biostratigraphy, biozonation.

\section{Introduction}

The criterion for defining the base of the Carboniferous system is placed to coincide with the First Appearance Datum (FAD) of the conodont species Siphonodella sulcata; the GSSP (Global Stratotype Section and Point) is located in La Serre Trench E' section (Paproth, Feist \& Flajs, 1991). Prob-lems in discrimination of $S i$. sulcata from the supposed ancestor Si. praesulcata were already known when the GSSP was established (e.g. Wang \& Yin, 1984; Ji, 1987). Flajs \& Feist (1988) published a biometric study of S. praesulcata and S. sulcata based on the La Serre faunas, demonstrating that transitional forms are very common. Despite these taxonomical uncertainities, the FAD of Si. sulcata was chosen to define the base of the Tournaisian. Further studies on the stratotype section have revealed other problems, such as lack of other important stratigraphic guides and the existence of reworking (e.g. Ziegler \& Sandberg, 1996; Casier, Lethiers \& Préat, 2002; Kaiser, 2009).

A redefinition of the Devonian-Carboniferous boundary (DCB) was determined necessary, and in 2008 the International Commission on Stratigraphy established a working group with the goal of proposing a new criterion for defining the boundary and find-ing a new GSSP. For that purpose several sections are under investigation around the world, including

$\nmid$ Author for correspondence: corradin@unica.it already-known localities (Mossoni, Corradini \& Spalletta, 2013; Kumpan et al. 2014b; Malec, 2014) and new locations (Bahrami, Corradini \& Yazdi, 2011; Becker et al. 2013; Girard et al. 2014; Komatsu et al. 2014; Kumpan et al. 2014b; Kalvoda, Kumpan \& Babek, 2015; Mossoni et al. 2015; Qie et al. 2015), and main fossil groups are subject to revision. Multiproxy studies including isotope stratigraphy, gamma-ray and magnetic susceptibility are also in progress (Kumpan et al. 2014a; Matyja et al. 2015).

This paper is a contribution to the activities of the working group, presenting a summary of the distribution of important uppermost Devonian and lowermost Carboniferous conodont species.

The interval from the Middle expansa Zone to the Lower duplicata Zone is considered in this paper, spanning a time interval of about $4 \mathrm{Ma}$ across the present boundary according to more recent geochronologic calibration (Becker, Gradstein \& Hammer, 2012; Davydov, Korn \& Schmitz, 2012). Possible new positions of the DCB in terms of conodont stratigraphy are presented and discussed and a new biozonation for the uppermost Devonian and lowermost Carboniferous is proposed.

\section{Conodont taxa across the DCB}

The distribution of the stratigraphically most important species of Bispathodus, Branmehla, Palmatolepis, 


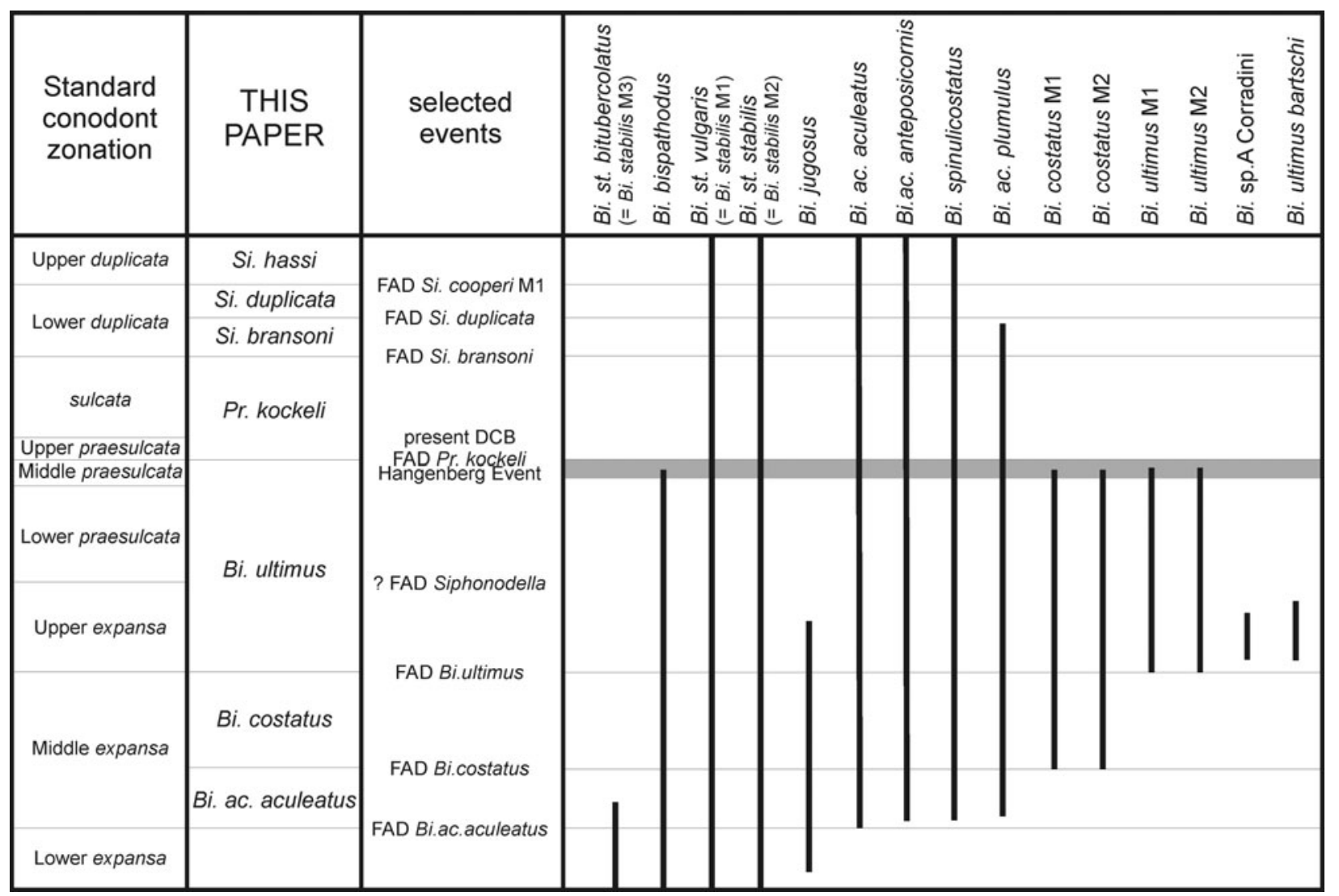

Figure 1. Distribution of Bispathodus across the Devonian-Carboniferous Boundary (data after Ziegler, Sandberg \& Austin, 1974; Sandberg et al. 1978; Ziegler \& Sandberg, 1984; Corradini, 2003; S. I. Kaiser, PhD Thesis, Ruhr-University Bochum, 2005; Kaiser et al. 2009; Kononova \& Weyer, 2013).

Polygnathus, Protognathodus, Pseudopolygnathus and Siphonodella and other genera were investigated, in order to analyse their potential for biostratigraphy across the DCB (Figs 1-4). All data available in literature were considered and integrated with unpublished data from our collections, mainly from the Carnic Alps and Sardinia.

It should be noted that some other genera have been proposed recently (e.g. Bizignathus Gatovsky, 2009; Neopolygnathus Voronsova, 1991 (in Barskov et al. 1991) and Polynodosus Vorontsova, 1993), detaching part of the species from another genus, mostly from the 'mega-genus' Polygnathus. This paper is not based on supraspecific taxonomy, and we do not want to enter into systematic discussions here even if, in our opinion, a single morphological variation is not sufficient to es-tablish a new genus. We therefore maintain the classical generic attribution for the species claimed to belong to Bizignathus, dubitatively included in Pseudopolyg-nathus; those of Neopolygnathus and Polynodosus are maintained in Polygnathus. These new genera are not widely accepted. Finally, it is important to note that most of the species included in Neopolygnathus are not widely distributed and are likely endemic forms, so their stratigraphic potential for a new criterion for the definition of the Devonian-Carboniferous boundary is rather limited.
The ranges of the taxa are presented on the basis of present standard zonations for the uppermost Devonian (Ziegler \& Sandberg, 1984) and lowermost Carboniferous (Sandberg et al. 1978). For comments on the zonation and discussion of the new zonation scheme depicted in Figures 1-4, see Section 3.

\section{2.a. Bispathodus}

Bispathodus is a genus widely distributed in the Famen-nian and Tournaisian strata and is represented by sev-eral species (Fig. 1), most of which have a broad geo-graphical distribution. In first approximation the genus can be subdivided into two stocks, one characterized by taxa with a relatively small basal cavity ('aculeatus branch' of Ziegler, Sandberg \& Austin, 1974) and the second with a wide basal cavity that extends to the pos-terior end ('bispathodus branch' of Ziegler, Sandberg \& Austin, 1974).

The genus was revised first by Ziegler, Sandberg \& Austin (1974), and later the 'ultimus Group' by Ziegler \& Sandberg (1984). Hartenfels (2011) elevated the morphotypes of Bi. stabilis to subspecies rank, and introduced a new subspecies. More recently Kononova \& Weyer (2013) approached the "ultimus Group' in a different way, partly refusing the revision by 


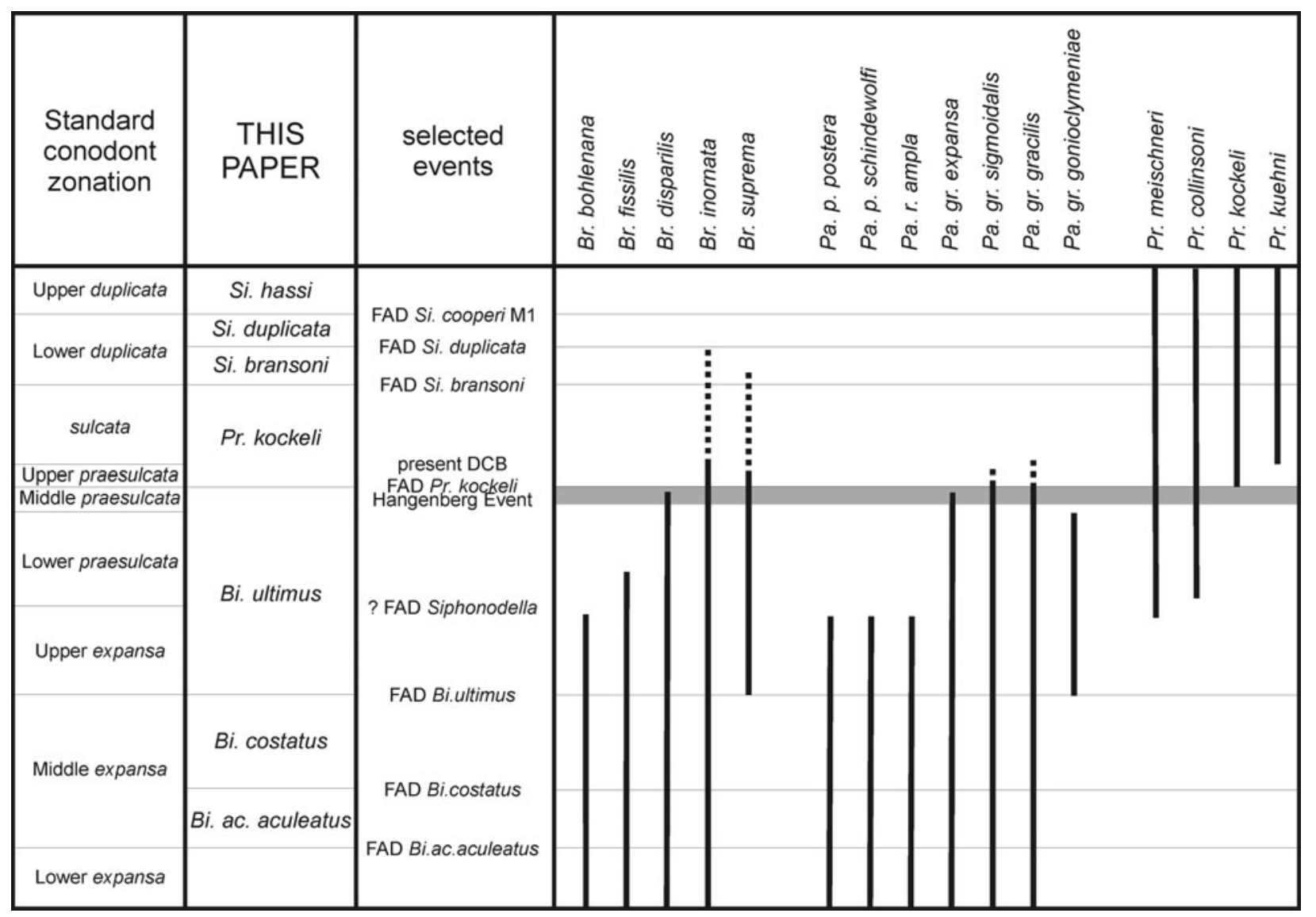

Figure 2. Distribution of Branmehla, Palmatolepis and Protognathodus across the Devonian-Carboniferous Boundary (data after Ziegler \& Sandberg, 1984; Ji \& Ziegler, 1993; Corradini, 2008; Kaiser et al. 2009; Corradini et al. 2011; and unpublished data).

Ziegler \& Sandberg (1984), but their revision needs to be carefully evaluated and is not followed here.

Bispathodus represents an important genus for the uppermost Famennian biostratigraphy. Ziegler (1962) named the last pre-Hangenberg Event zone after $B i$. costatus (Branson) and Ziegler \& Sandberg (1984) selected Bi. aculeatus aculeatus (Branson \& Mehl) and Bi. ultimus (Bischoff) as markers of the Middle and Upper expansa zones, respectively.

A large radiation of species of Bispathodus occurred during latest Famennian time: 11 taxa have their first appearance between the Lower and the Upper expansa zones. Bi. stabilis stabilis (Branson \& Mehl) $(=B i$. stabilis Morphotype 2 of Ziegler, Sandberg \& Aus-tin, 1974) is often documented from the base of the Lower expansa Zone. The taxon was used by Harten-fels (2011) to approximate the base of the Lower ex-pansa Zone, renamed stabilis Zone in his 'Overregional Zonation', because the marker Pa. gracilis expansa is not present in Central Europe and Morocco. However, it should be noted that the species has an early first occurrence in the Carnic Alps and Thuringia, where it enters within the Upper trachytera Zone (Spalletta \& Perri, unpubl. data; Girard et al. unpubl. data). Bi. jugosus branched from Bi. st. stabilis in the upper part of the Lower expansa Zone.

The early part of the Middle expansa Chron represented a period of wide radiation of Bispathodus: as already mentioned Bi. ac. aculeatus is the marker of the base of the zone, and Bi. ac. anteposicornis (Scott) and Bi. ac. plumulus (Rhodes at al.) appeared slightly later. The latter taxon was moved to Clydagnathus by Hartenfels (2011), but this change of generic attribution should be carefully evaluated. Both the morphotypes of Bi. costatus (Branson) enter in the central part of the zone. The last radiation of Bispathodus happened in the Late expansa Chron, and involved the 'ultimus Group': the two morphotypes of Bi. ultimus have an almost simultaneous first appearance at the base of the zone, and related taxa have been reported regionally in slightly higher levels: Bi. ultimus bartschi Kononova \& Weyer in Thuringia and Bispathodus sp. A Corradini in Sardinia. No species of Bispathodus originated after the Upper expansa Zone (Fig. 1).

Bispathodus bispathodus Ziegler et al., Bispathodus costatus and Bispathodus ultimus did not survive the Hangenberg Event (Ziegler \& Sandberg, 1984), whereas Bispathodus stabilis, Bi. spinulicostatus and Bi. aculeatus are reported in the lower Carboniferous at least up to the Lower crenulata Zone (Sandberg et al. 1978).

\section{2.b. Branmehla and Mehlina}

Branmehla and Mehlina are ozarkodinids characterized by a single row of denticles on the processes. In 


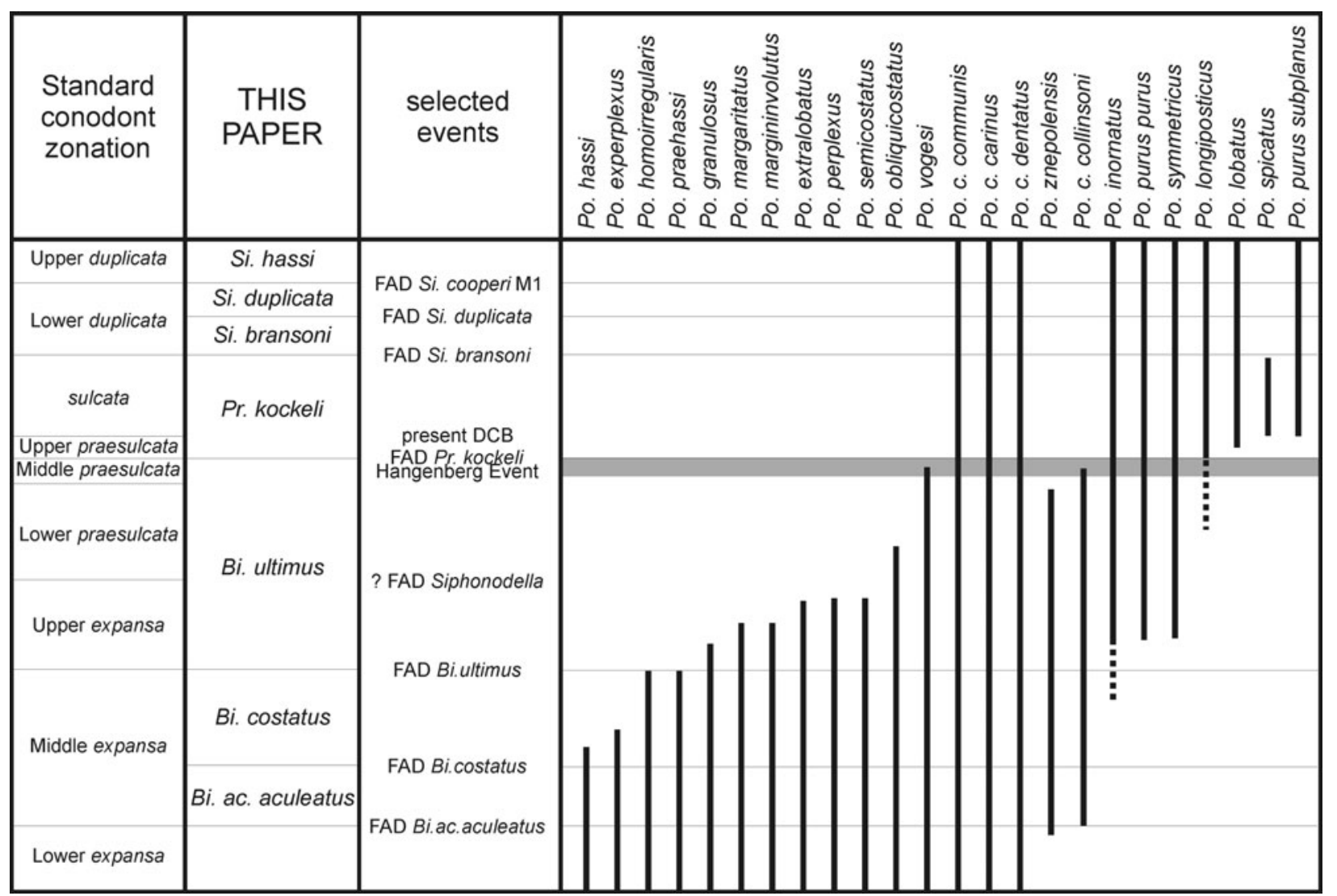

Figure 3. Distribution of selected taxa of Polygnathus across the Devonian-Carboniferous Boundary (data after Sandberg et al. 1978; Ziegler \& Sandberg, 1984; Wang \& Yin, 1988; Perri \& Spalletta, 1991, 2000a; Ji \& Ziegler, 1993; Corradini, Barca \& Spalletta, 2003; Corradini, 2008; Hartenfels 2011; Qie et al. 2014; and unpublished data).

general they do not represent a major component of the conodont association, even if some species are quite abundant in some levels.

The distribution of Branmehla is limited to the uppermost Devonian and lowermost Carboniferous strata (Fig. 2). Branmehla bohlenana (Helms) ranges up to the Upper expansa Zone, while Br. fissilis (Branson \& Mehl) enters in the Lower praesulcata Zone. Branmehla suprema (Ziegler), with a wide asymmetrical basal cavity, is a characteristic species of the Upper expansa and Lower praesulcata zones, but is tentatively recorded also from the lowermost Tournaisian strata of the Graz Palaeozoic and French Pyrenees (Kaiser et al. 2009). The report (not figured) of Br. fissilis from the Tournaisian of China (Hou et al. 1985) should be confirmed and possible reworking should be excluded before considering these unusually high occurrences; the presence of $B r$. werneri in the Carboniferous of Dapoushang section (Wang \& Yin, 1988) is disregarded because the figured specimens belong to another taxon.

Branmehla inornata (Branson \& Mehl) is a longranging taxon that survived the Hangenberg Event (Ziegler \& Sandberg, 1984) and entered the Carboniferous system (Over, 1992; Kaiser et al. 2009; Bahrami, Corradini \& Yazdi, 2011). Mehlina strigosa (Branson \& Mehl) was once considered extinct at the DCB, but recently it has been documented together with definitely Carboniferous associations (Kaiser et al. 2009; Bahrami, Corradini \& Yazdi, 2011).

\section{2.c. Palmatolepis}

Palmatolepis is the dominant genus of the Upper Devonian pelagic environment. Numerous species and subspecies have been established in the Frasnian and Famennian strata, but the diversity decreases within the upper Famennian and only a few taxa are documented in the uppermost Famennian deposits (Fig. 2).

The most common taxon in that stratigraphic interval is $P a$. gracilis, represented by several subspecies. Pa. gr. expansa Sandberg \& Ziegler ranges from the base of the Lower expansa Zone up to the level of the Hangenberg Event, but in some parts of the world it is a rare taxon (i.e. central Europe). Palmatolepis gr. gonioclymeniae Müller is documented from the Upper expansa Zone to just below the Hangenberg Event; its LAD was chosen by Ziegler \& Sandberg (1984) to indicate the base of their Middle praesulcata Zone, but this definition is often not applicable because the taxon is very rare or absent (Corradini, 2008; Kaiser et al. 2009). The most successful taxa of this stock are the nominal species, Pa. gr. gracilis Branson \& Mehl and $P a$. gracilis sigmoidalis Ziegler, which ranged for most 
of the Famennian age and became extinct within the Hangenberg Event, or slightly later.

Beside Pa. gracilis, only a few taxa of Palmatolepis belonging to the 'perlobata' and 'rugosa' groups occur up to the Upper expansa Zone: Pa. perlobata postera Ziegler; Pa. $p$. schindewolfi Müller; and Pa. rugosa ampla Müller (Fig. 2).

\section{2.d. Polygnathus}

Polygnathus is the most abundant and differentiated conodont genus of the Devonian and Carboniferous strata: Becker $(2012,2013)$ listed hundreds of names of species (and subspecies) attributed to Polygnathus. About 40 taxa are documented in the uppermost Devonian and lowermost Carboniferous strata (Fig. 3), but few have an important stratigraphic value either due to a long range or a restricted regional distribution.

Many species became extinct within the Middle and Upper expansa zones (Fig. 3). Polygnathus znepolensis Spassov is documented up to the top of the Middle praesulcata Zone, and Po. vogesi Ziegler ranges up to the Hangenberg Event. It should be noted that the latter taxon was reported from Tournaisian deposits after a Lazarus phase (see Kaiser et al. 2009, p. 124), but these occurrences should be confirmed in order to exclude homeomorphism or taxonomic confusion with Po. $c$. carinus, which is quite similar in upper view.

The most common polygnathid species across the DCB is Polygnathus communis Branson and Mehl (= Neopolygnathus Vorontsova), which has been subdivided into several subspecies. Some of the subspecies have a wide geographical distribution, such as $P o$. c. communis, Po. c. carinus Hass and Po. c. dentatus Druce, but are documented from the Famennian into the Tournaisian strata, whereas Po. c. collinsoni Druce is limited to the uppermost Famennian deposits. Other subspecies (e.g. Po. c. quadratus Wang, Po. c. renatae Corradini \& Spalletta, Po. c. shangmiaobeiensis Qin et al. and others) have shorter ranges but are geographically limited.

Polygnathus purus purus, which Voges (1959) indicated as an index of the basal Carboniferous, have been reported from Upper Devonian strata before the entry of Siphonodella in several North Gondwana regions (Corradini, Barca \& Spalletta, 2003; Bahrami, Corradini \& Yazdi, 2011; Girard et al. 2014). Polygnathus purus subplanus enters more or less around the present DCB (Kaiser et al. 2009), but it is not a common taxon; this also applies for Po. spicatus Hinde, which has a range limited to the present sulcata Zone (Sandberg et al. 1978; Qie et al. 2014).

Other species such as Polygnathus inornatus and P. symmetricus originate in the upper Famennian and range well into the Tournaisian strata (Sanz López et al. 1999; Corradini, 2008; Bahrami, Corradini \& Yazdi, 2011). Polygnathus longiposticus have been reported before the Hangenberg Event only in China (Wang \& Yin, 1988).

\section{2.e. Protognathodus}

Protognathodus is a short-ranging genus, known from the uppermost Famennian to the Tournaisian strata. Its stratigraphic potential around the DCB is well known since Ziegler (1969) introduced the 'Protognathodus fauna' to define the uppermost Devonian strata, and later Ziegler \& Sandberg (1984) defined the base of the last Devonian zone, the 'Upper praesulcata Zone', by the entry of Pr. kockeli. However, it should be noted that in some regions such as in Poland the genus is very rare.

The genus has been revised by Corradini et al. (2011). Four species of Protognathodus are known in the time frame across the DCB (Fig. 2): Pr. meischneri Ziegler; Pr. collinsoni Ziegler; Pr. kockeli (Bischoff); and Pr. kuehni Ziegler \& Leuteritz. Two more species occur in the middle Tournaisian: Pr. praedelicatus Lane et al. and Pr. cordiformis Lane et al.

Protognathodus meischneri, the oldest species of the genus, evolved from Bispathodus stabilis (Zieg-ler, 1969) during late Famennian time by a variation in the position and shape of the basal cavity (cup). In Protognathodus the basal cavity extends to the posterior end of the element and is more rounded and inflated; Pr. meischneri has an almost symmetrical and unornamented cup. The first occurrence of Pr. meischneri is reported from the Upper expansa Zone (Corradini, Barca \& Spalletta, 2003; Corradini et al. 2011). In the very early part of its range Pr. meischneri gave rise to Pr. collinsoni, characterized by the occurrence of scattered nodes on the upper surface of the slightly asymmetrical cup. Both these species range to within the Upper duplicata Zone (Over, 1992).

Protognathodus kockeli, characterized by an asymmetrical cup covered by at least one longitudinal row of nodes, evolved from Pr. collinsoni just after the Hangenberg Event. It ranges up to the lower part of the Lower crenulata Zone in North America (Sandberg et al. 1978), whereas elsewhere it is limited to the sandbergi Zone. Protognathodus kockeli is the marker of the Upper praesulcata Zone (= kockeli Zone after Kaiser et al. 2009, the last Devonian biozone) and is the most abundant and widely documented species of Protognathodus. It has a wide geographic distribution, but in many regions it occurs only in Carboniferous strata (Corradini et al. 2011). However, it should be noted that a hiatus occurs above the Hangenberg Shales equivalents in several sections around the world, and the older part of the range of Pr. kockeli is therefore often not documented.

Protognathodus kuehni is distinguished by robust transverse ridges on the upper surface of the cup running radially from the margins to the carina, which can be suppressed. It evolved from Pr. kockeli and ranges from at or just above the present DCB to the sandbergi Zone (Lane, Sandberg \& Ziegler, 1980). The first occurrence of Pr. kuehni was used by Kaiser et al. (2009) to approximate the DCB in sections where siphonodellids are absent. However, it is in general an extremely 


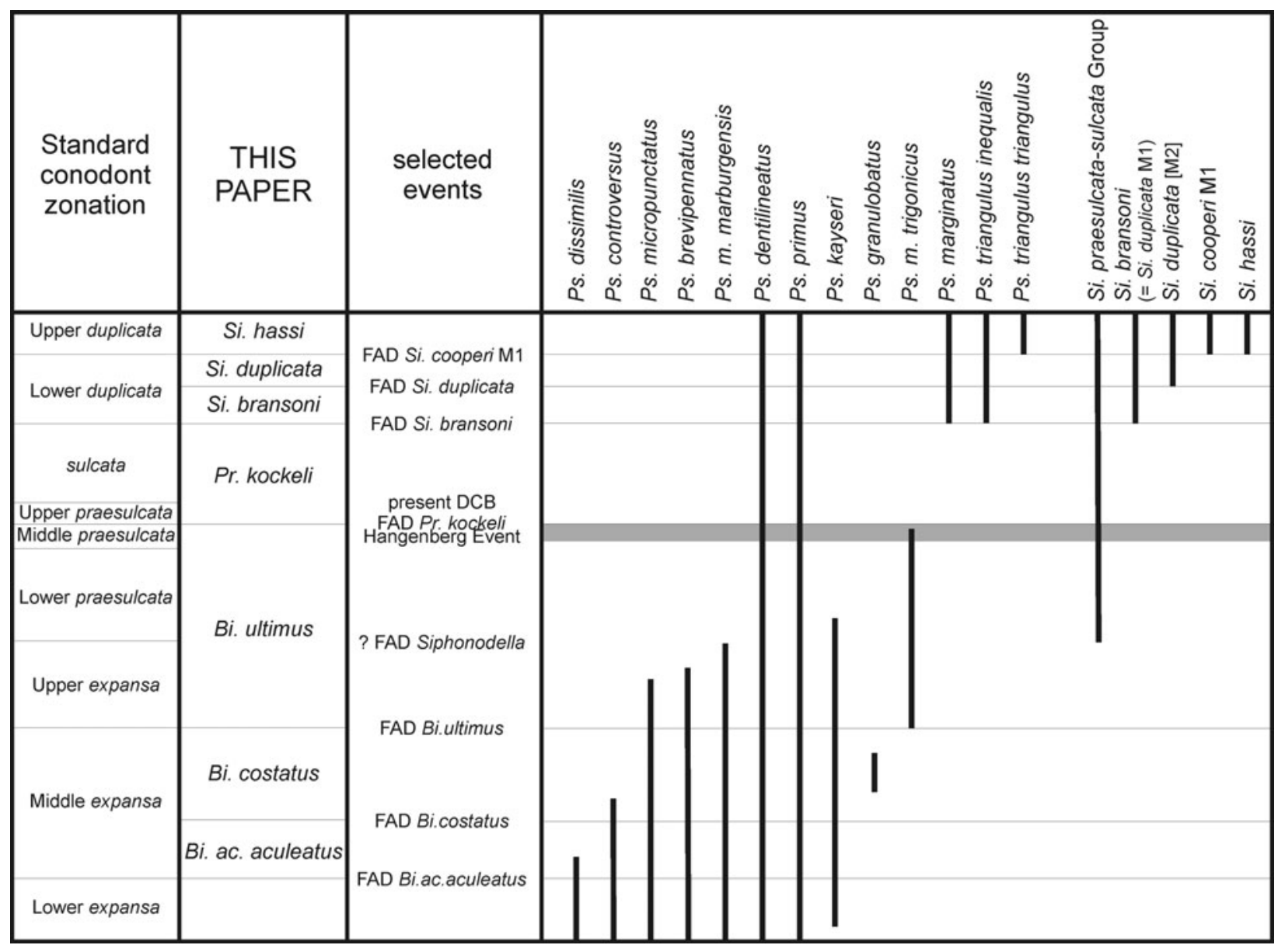

Figure 4. Distribution of Pseudopolygnathus and Siphonodella across the Devonian-Carboniferous Boundary (data after Sandberg et al. 1978; Klapper in Ziegler, 1981; Ziegler \& Sandberg, 1984; Perri \& Spalletta, 1991; Ji \& Ziegler, 1993; Corradini, Barca \& Spalletta, 2003; Corradini, 2003, 2008; Kaiser et al. 2009; Hartenfels, 2011; and unpublished data).

rare taxon with a restricted range in many sections and, outside the type area, it often occurs only in higher stratigraphic levels (Corradini et al. 2011).

\section{2.f. Pseudopolygnathus}

Pseudopolygnathus is a relatively abundant and widely distributed genus in the uppermost Famennian and lowermost Tournaisian strata (Fig. 4). However, the genus underwent a crisis during the Middle and Late expansa chrons, when several Devonian species became extinct: Ps. brevipennatus Ziegler; Ps. controversus Sandberg \& Ziegler; Ps. dissimilis (Helms \& Wolska); Ps. marburgensis marburgensis Bischoff \& Ziegler; and Ps. micropunctatus Bischoff \& Ziegler. Pseudopolygnathus? kayseri Bischoff \& Ziegler entered into the Lower praesulcata Zone. It should be noted that Ps.? kayseri and Ps. dissimilis were moved to the new genus Bizignathus by Gatovsky (2009) and Hartenfels (2011), respectively.

Only a few taxa are documented around the Devonian-Carboniferous boundary: Ps. dentilineatus Branson; Ps. marburgensis trigonicus Ziegler; PS. multistriatus Mehl \& Thomas; and Ps. primus Branson $\&$ Mehl. None of these seem to have a strong stratigraphic importance.
Pseudopolygnathus marburgensis trigonicus became extinct during the Hangenberg crisis (Ziegler \& Sandberg, 1984). Pseudopolygnathus dentilineatus, once reputed to have its first occurrence together with Protognathodus kockeli above the Hangenberg Event (Voges, 1959), has been reported from the Middle expansa Zone in Devonian strata (Klapper in Zieg-ler, 1981). Pseudopolygnathus primus and Ps. dentilineatus have long ranges, at least from the Lower expansa Zone (Klapper in Ziegler, 1981) to the Lower crenulata Zone (Sandberg et al. 1978).

Pseudopolygnathus multistriatus enters at the base of Carboniferous system, but it is a rare taxon. A larger radiation of Pseudopolygnathus took place during the Tournaisian age, when several species have their first appearance within the Lower duplicata Zone and in higher levels.

\section{2.g. Siphonodella}

Two taxa have been established within the early range of the genus Siphonodella lineage: Siphonodella praesulcata Sandberg and Siphonodella sulcata (Huddle). Although problems in discrimination of S. praesulcata from $S$. sulcata were evidenced by numerous authors in several parts of the world (Ji, 1987; Flajs \& Feist, 
1988; Wang \& Yin, 1988), the base of the Carboniferous system was defined by the First Occurrence of Siphonodella sulcata within the claimed S. praesulcata - S. sulcata lineage (Paproth, Feist \& Flajs, 1991).

The diagnoses of the two taxa are not clear and they overlap each other (Kaiser \& Corradini, 2011). According to the original diagnosis (Sandberg, in Sandberg, Streel \& Scott, 1972), Siphonodella praesulcata has a slightly arched, narrow platform ornamented on both sides by weak to obsolescent transverse ridges, separated from the straight to slightly curved carina by wide adcarinal troughs; the basal cavity is straight to slightly curved. The author reports that the species can be distinguished from $S$. sulcata from the fact that the latter has a more asymmetrical, slightly curved, platform with a stronger ornamentation and, mainly, a strongly curved pseudokeel. In fact, the emended diagnosis (Sandberg, in Sandberg, Streel \& Scott, 1972) of Si. sulcata reads: 'slightly asymmetrical arched platform is ornamented on both sides by transverse ridges, which are separated from the strongly curved nodose carina by narrow adcarinal grooves. The strongly curved basal cavity...'

However, as demonstrated by Kaiser \& Corradini (2011), only a few specimens fit one or the other definition well; the great majority of specimens show features intermediate between those listed for the two taxa. Furthermore, the claimed phylogenetic transition from $S$. praesulcata to $S$. sulcata is not recorded in the DCB GSSP section at La Serre, where the supposed $S$. praesulcata - S. sulcata lineage was based on reworked elements found in sediments derived from different source areas (Ziegler \& Sandberg, 1996; Kaiser, 2009).

It should also be noted that specimens assignable to Siphonodella praesulcata-sulcata group, both with straight and curved shape of the carina and basal cavity, have been illustrated and described as species of Polygnathus in the literature (e.g. some of the specimens of Polygnathus sp. D and Polygnathus sp. E of Kononova $\&$ Weyer, 2013). Often these specimens came from levels yielding an uppermost Famennian association.

It is worthwhile mentioning that the lost holotype of S. sulcata was from a level likely yielding Carboniferous conodonts at least referable to the duplicata Zone (Evans et al. 2013), therefore representing a late morphotype. However, after a complete revision of the early siphonodellids, it cannot be excluded that other species of Siphonodella may be discriminated within the early part of the lineage.

In higher levels a very good datum point is represented by the FAD of Si. bransoni Ji (=Si. duplicata M1) (Fig. 4), a well-known, easy to identify and relatively abundant species with a wide geographical distribution. Establishing the species, Ji (1985) reported the description of Si. duplicata M1 of Sandberg et al. (1978), but did not indicate a holotype. The designation of a type is needed, possibly reconsidering the collections by Canis (1968), mentioned by Sandberg et al. (1978) and Ji (1985). According to Sandberg et al. (1978, p. 105), Si. bransoni 'evolved from Si. sulcata by development of a complete rostrum on both side of the anterior end of the platform'.

A different group of species of Siphonodella are rep-resented by the so-called 'naked Siphonodellas', re-garded by several authors as typical of shallowwater facies. These forms are documented at the base of the Carboniferous system, mainly in China and Russia (Ji \& Ziegler, 1992; Qie et al. 2014) and are rare else-where. Siphonodella homosimplex Ji \& Ziegler is the oldest representative of the group and has its FAD close to the present DCB. Shortly after, Si. levis (Ni), Si. semi-chatovae Kononova \& Lipnjagov and Si. bella Kononova \& Migdisova first appear; Si. sinensis Ji and Si. quasinuda Gagiev, Kononova \& Pazukin enter at the base of the Lower duplicata Zone. Other taxa, such as Si. dasaibaensis Ji et al. and Si. eurylobata $\mathrm{Ji}$, are documented higher in the Tournaisian strata.

Ji \& Ziegler (1992) proposed an alternate zonation scheme for the shallow-water facies of the lower and middle Tournaisian strata, defining six zones based on the entries of species of naked siphonodellas: homosim-plex Zone; levis Zone; sinensis Zone; dasaibaensis Zone; Early eurylobata Zone; and Late eurylobata Zone.

\section{Conodont zonation across the DCB}

The conodont zonation scheme in use for the Upper Devonian and lower Tournaisian strata is a combination of the 'Late Devonian Standard Conodont Zonation' (Ziegler \& Sandberg, 1990), and the Late Devonian -early Carboniferous zonation of Sandberg et al. (1978). Variations and improvements to these schemes were proposed by Ji (1985), Corradini (2008), Kaiser et al.(2009) and Hartenfels (2011), but these modifications have not been widely used up to now. Some of these proposals are accepted here.

The taxonomic revision of taxa and the updating of their stratigraphic and geographic distribution im-ply a reconsideration of the zonation scheme for up-permost Famennian and lower Tournaisian strata, in order to achieve a new, global, zonation. Before focus-ing on open problems in the zonation schemes in use, it is necessary to briefly summarize the history of the conodont zonation across the Devonian-Carboniferous Boundary.

\section{3.a. Review of former zonation schemes}

The first zonation scheme for the Upper Devonian strata was provided by Ziegler (1962) who discriminated 24 conodont zones before the Hangenberg Event, mainly based on sections in Germany. In the uppermost Famen-nian strata Po. styriacus and Spathognathodus costatus (now Bi. costatus) were chosen as index taxa for two zonal groups, both subdivided into a Lower, a Middle and an Upper part. The time frame of interest of this paper includes the Upper styriacus, the Lower costatus, the Middle costatus and the Upper costatus zones sensu Ziegler (1962) (Fig. 5). The Upper styriacus Zone cor- 


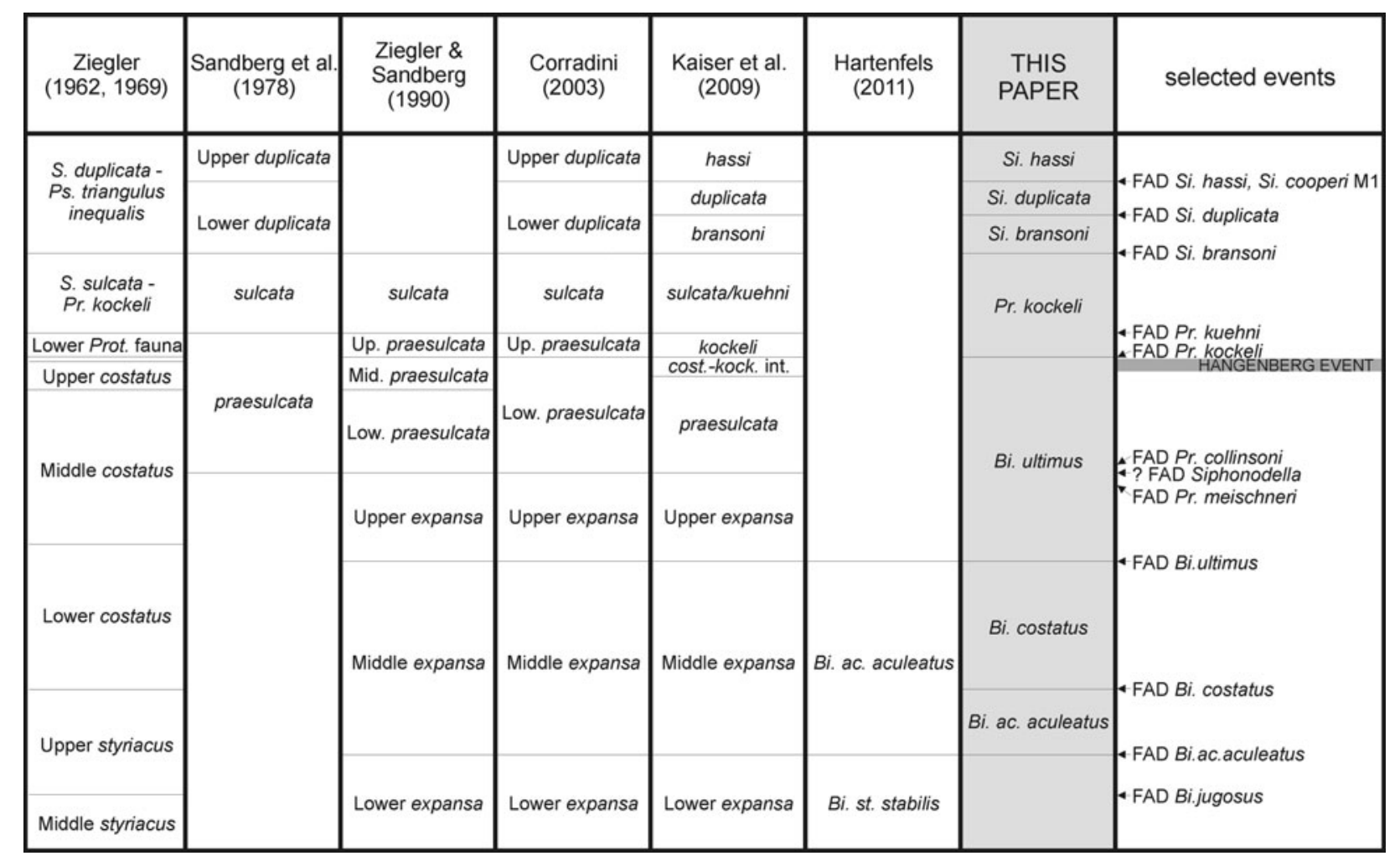

Figure 5. Main conodont zonation schemes across the Devonian-Carboniferous boundary, with indication of the main bioevents useful for stratigraphy. Thickness of zone is calibrated according to their length, as estimated in the Devonian and Carboniferous chapters of The Geologic Time Scale 2012 (Becker, Gradstein \& Hammer, 2012; Davydov, Korn \& Schmitz, 2012).

responded to the upper part of the range of Po. styriacus, above the entry of Ps. brevipennatus, Ps. dentilineatus and Sp. jugosus (now Bi. jugosus). The base of Lower costatus Zone was indicated by the FAD of the nom-inal species; the Middle costatus Zone fell in the central part of the range of Bi. costatus together with Pa. gr. gonioclymeniae and Bi. ultimus; and the Upper costa-tus Zone was defined as the upper part of the range of Bi. costatus and Bi. ultimus after the extinction of Pa.gr. gonioclymeniae. This zonation was confirmed by Ziegler (1971, 1979), with the addiction of the Lower Protognathodus Fauna that Ziegler (1969) documented from the uppermost part of the Wocklumeria-Stufe.

Voges $(1959,1960)$ introduced a zonation scheme for the lowermost Carboniferous in Germany. In the 'Gattendorfia Stufe' he distinguished three zones: the kockeli-dentilineata Zone; the Siphonodella-triangulus inequalis Zone; and the Siphonodella-triangulus triangulus Zone. Ziegler (1969) updated this zonation renaming the oldest zones Siphonodella sulcata - Protognathodus kockeli Zone and Siphonodella duplicatatriangulus inequalis Zone, and proposed the equivalence of these zones with the Siphonodella sulcata and Siphonodella duplicata zones described in North America by Klapper (in Sandberg \& Klapper, 1967).

Sandberg et al. (1978) introduced a zonation scheme for the uppermost Famennian and most of the Tournaisian strata based on the evolution of genus $\mathrm{Si}$ phonodella. In this scheme the entry of Si. praesulcata discriminates the last Devonian zone and that of $\mathrm{Si}$. sulcata markes the base of the Carboniferous. The sub- sequent Lower duplicata Zone is distinguished by the FAD of Si. duplicata, and the Upper duplicata Zone by the entry of Si. cooperi Morphotype 1.

Ziegler \& Sandberg (1984) revised the upper part of the Upper Devonian zonation, naming all the zones before the entry of Si. praesulcata after species of genus Palmatolepis. The styriacus and costatus zonal groups of Ziegler (1962) were replaced by the postera and expansa zonal groups. The former Upper styriacus Zone was replaced by the Lower expansa Zone, the base of which is indicated by the FAD of Pa. gr. expansa; the Middle expansa Zone is marked by the entry of Bi. $a c$. aculeatus; and the Upper expansa Zone is marked by those of Bi. ultimus. Siphonodella praesulcata was chosen to name the last group of zones of the Devonian, in order to connect the Upper Devonian zonation based on Palmatolepis with the lower Carboniferous zonation based on Siphonodella. The Lower praesulcata Zone is marked by the FAD of the nominal species, the Middle praesulcata Zone by the extinction of Pa. gr. gonioclymeniae and the Upper praesulcata Zone by the entry of Pr. kockeli. Surprisingly, even though some of the boundaries of the new zones are defined exactly as those of the former zones, in both the text and figures of Ziegler \& Sandberg (1984) there are some discrep-ancies in the correlation and definition of the old and the new zonal schemes. The LAD of Pa. gr. goniocly-meniae in Ziegler (1962) defines the base of the Upper costatus Zone, whereas in Ziegler \& Sandberg (1984) it indicates the base of the Middle praesulcata Zone. Further, the bases of the biozones do not correspond 
(see Ziegler \& Sandberg, 1984, p. 184, figs 1-4) although they are supposed to be defined with the same criterion. Only the equivalence between the Lower Protognathodus fauna and the Upper praesulcata Zone was correctly indicated.

Later the same authors (Ziegler \& Sandberg, 1990) updated the Upper Devonian zonation without mak-ing any variation in the uppermost Famennian strata, and renamed the scheme the 'Late Devonian Standard Conodont Zonation'. In addition, Ziegler \& Sandberg (1994) claimed this zonation as a 'phylogenetic zonation', where zones are 'defined from the first occurrences of an ancestral species to the first occurrence of the next younger descendant species' (Sandberg \& Ziegler, 1996, p. 261). This definition was strongly cri-ticized (Corradini, 2008; Kononova \& Weyer, 2013) be-cause that scheme is based on both first occurrences and extinction within several genera and therefore, apart from a few short intervals, was not a phylogenetic zon-ation. The taxonomic concept on which the so-called standard zonation is based had already been rejected by Klapper \& Foster (1993) for Frasnian species.

The Ziegler \& Sandberg (1990) scheme was widely used in the last decades, even if some problems arose. In the uppermost Famennian strata the main concern was with the definition of the Middle praesulcata Zone, defined by the extinction of Pa. gr. gonioclymeniae, a taxon that is not common outside Germany. Problems in discrimination of that zone were evidenced by Over (1992), Perri \& Spalletta (2000a) and Corradini (2008). S. I. Kaiser (PhD Thesis, Ruhr-University Bochum, 2005) reported that 'the base of the Middle praesul-cata cannot be regarded as the approximation of an isochronous level, and its recognition does not allow re-liable biostratigraphical and geochemical correlations'. On the basis of these considerations, Corradini (2008) proposed to expand the Lower praesulcata Zone up to the entry of Pr. kockeli, essentially eliminating the Middle praesulcata Zone.

Kaiser et al. (2009) accepted the proposal to aban-don the Middle praesulcata Zone and introduced a new interval zone, the 'costatus-kockeli Interregnum (CKI)', corresponding to the Hangenberg conodont ex-tinction event. This interval is equivalent to the upper-most part of the former Middle praesulcata Zone. In addition these authors renamed the zones across the DevonianCarboniferous boundary by the name of the index taxon, and adopted for the Tournaisian strata proposal by Ji (1985) based on Siphonodella: sulcata Zone, bransoni Zone, duplicata Zone, hassi Zone, etc.(Fig. 5). All these zones, as well as several middle and upper Famennian zones renamed by Hartenfels (2011), are named after the index taxon where the first appear-ance indicates the base of the zone. Kaiser et al. (2009) also renamed the sulcata Zone as sulcata/kuehni Zone, suggesting the use of the FAD of Pr. kuehni as an index when Si. sulcata was not present.

Finally, a chronologic calibration of the zones was attempted in the Geological Time Scale 2012 (Devo-nian: Becker, Gradstein \& Hammer, 2012; Carbonifer- ous: Davydov, Korn \& Schmitz, 2012). The biozones in Figure 5 are calibrated according to these results where a few zones, such as the Middle praesulcata and the kockeli zones, were very short and others definitely longer (i.e. Middle expansa Zone).

\section{3.b. Proposal of a new zonation}

A zonation that can be used globally should be based on index taxa easy to recognize, with a well-known stratigraphic range and a broad geographic distribution. Taxa whose taxonomic attribution is not clear and/or need taxonomic revision should be avoided. In the ma-jority of cases candidate species do not have a wide geographical distribution or their first occurrence is not simultaneous in different regions, or in some areas are rare.

Zonation schemes can also be developed for limited geographic areas only. These regional zonations can be based on endemic taxa, or on taxa with a wide and limited geographic distribution, and may allow more detailed correlation within the region than the standard zonation.

In the uppermost Devonian and lowermost Carboniferous strata only a few taxa have the characteristics to define the zones of a possible global zonation. As an example, species of Siphonodella in the upper part of the range of the genus (the entry of Si. bransoni and above) may be very good markers, but it is better to avoid the use of the early representatives because of significant taxonomic uncertainties. Some species of Bispathodus can be good markers in the uppermost Famennian strata. Among Protognathodus only Pr. kocke-li can be used, while the other representatives of the genus have a very low stratigraphic potential due to their rarity (Corradini et al. 2011).

A new zonation for the uppermost Famennian and lowermost Tournaisian strata is presented in the following (Fig. 5). The stratigraphic interval considered is equivalent to the former Middle expansa to the Lower duplicata zones. All the zones are defined by First Ap-pearance Datum (FAD) of well-known taxa and are named after the index species. Taxonomic references of the index taxa are indicated, and the type specimens (or reference specimens) are illustrated in Figure 6.

\section{3.c. The Bispathodus ac. aculeatus Zone}

\section{Lower limit: FAD of Bispathdus aculeatus aculeatus}

\section{Upper limit: FAD of Bispathodus costatus}

Remarks: The Bi. aculeatus Zone is equivalent to the lower part of the Middle expansa Zone of Ziegler \& Sandberg (1984) and to the upper part of the Upper styriacus Zone of Ziegler (1962). Hartenfels (2011) proposed a Bi. aculeatus Zone in his 'Overregional Zonation', but extended the upper boundary up to the FAD of Bi. ultimus, therefore also including the $B i$. costatus Zone which he considered as a subzone.

Notes on the index taxon: The holotype was not indicated by Branson \& Mehl (1934a) when the species 


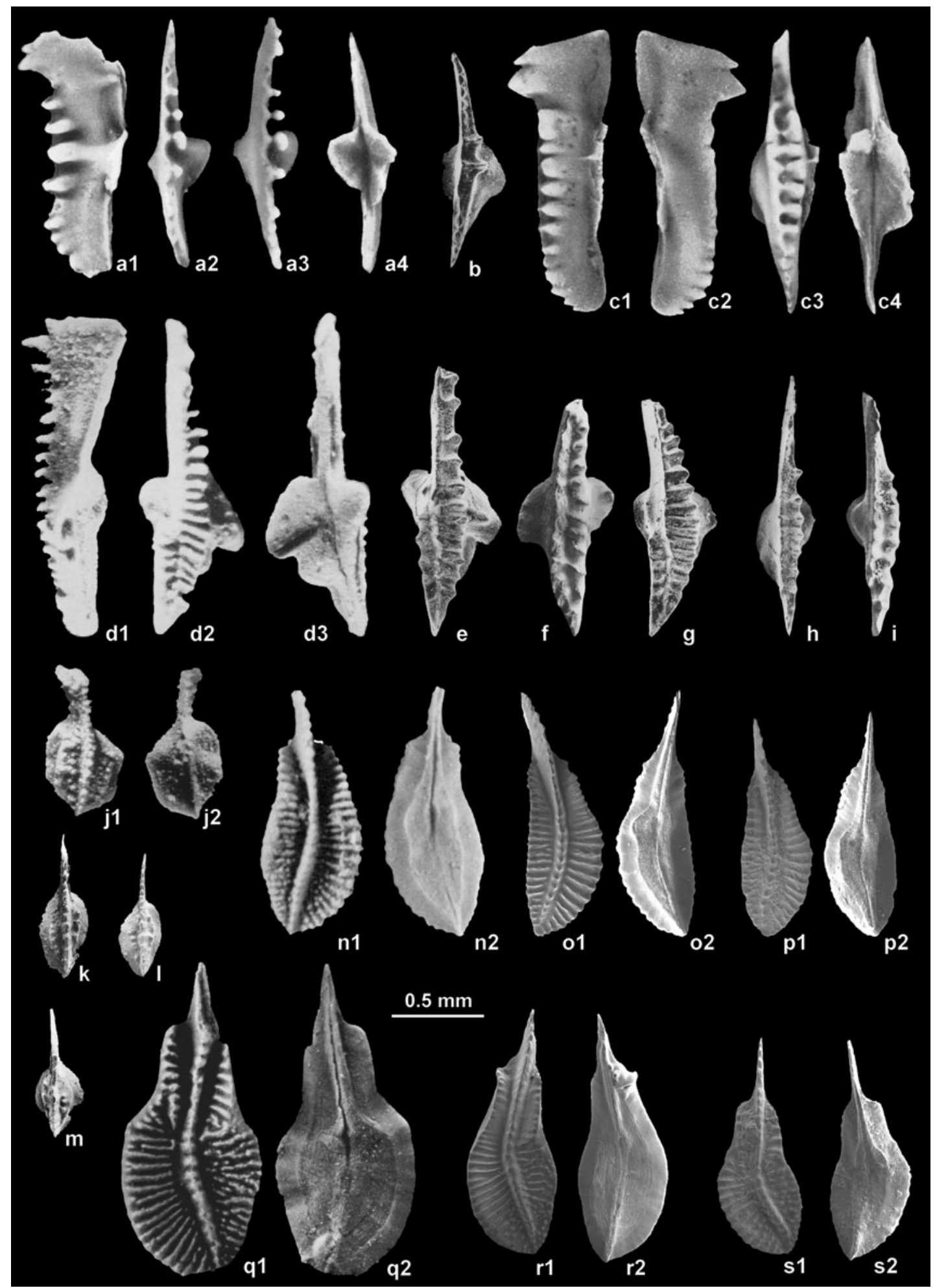

Figure 6. (a) Bispathodus aculeatus aculeatus (Branson \& Mehl). Lectotype, lateral (a1), upper (a2), upper-lateral (a3) and lower (a4) views. Tributary of South Fork of North River, Marion County, Missouri. Refigured after Ziegler, Sandberg \& Austin (1974). (b) Bispathodus aculeatus aculeatus (Branson \& Mehl), upper view. Corona Mizziu section, Sardinia, sample CM I 25 of Corradini (2003). (c) Bispathodus costatus (Branson). Holotype, inner-lateral (c1), outer-lateral (c2), upper (c3) and lower (c4) views. Hannibal Shale, section at Lovers Leap. refigured after Ziegler (in Ziegler, 1975). (d) Bispathodus ultimus (Bischoff). Holotype, lateral (d1), upper (d2) and lower (d3) views. Abandoned quarry between the villages of Wocklum and Mellen, SW slope of Burg-Berg, Rhenish Slate Mountain. Refigured, after Bischoff (1957, pl. 4, fig. 24a-c). (e) Bispathodus ultimus (Bischoff). Morph 1 of Ziegler \& Sandberg (1984), upper view. Corona Mizziu section, Sardinia, sample CM I 24 of Corradini (2003). (f) Bispathodus ultimus (Bischoff). Morph 2 of Ziegler \& Sandberg (1984), upper view. NW Poland (Pomerania), borehole section Rzeczenica-1, depth 3002.5 m. (g) Bispathodus ultimus (Bischoff). Morph 2 of Ziegler \& Sandberg (1984), upper view. Corona Mizziu section, Sardinia, sample CM I 26 of Corradini (2003). (h) Bispathodus costatus (Branson), upper view. Corona Mizziu section, Sardinia, sample CM I 25B of Corradini (2003). (i) Bispathodus costatus (Branson), upper view. NW Poland (Pomerania), borehole section Rzeczenica-1, depth 3002.5 m. (j) Protognathodus kockeli Bischoff. Holotype, upper (j1) and lower (j2) views. Abandoned quarry between the villages of Wocklum 
was erected; Ziegler (1962) chose the lectopype as the element figured by Branson \& Mehl (1934a) in plate 17 , figure 11 . The lectotype was refigured by Ziegler, Sandberg \& Austin (1974, pl. 2, fig. 1) and Ziegler (in Ziegler 1975, Bispathodus pl. 1, fig. 1). For a revised diagnosis and description refer to Ziegler et al. (1974).

\section{3.d The Bispathodus costatus Zone}

Lower limit: FAD of Bispathdus costatus

\section{Upper limit: FAD of Bispathodus ultimus}

Remarks: The Bi. costatus Zone is equivalent to the upper part of the Middle expansa Zone of Ziegler \& Sandberg (1984) and to the Lower costatus Zone of Ziegler (1962). Hartenfels (2011) proposed a Bi. costatus subzone in Germany and Poland, to discriminate the upper part of the Bi. aculeatus Zone.

Notes on the index taxon: The species was erected by Branson (1934) who illustrated the holotype in plate 27 , figure 13 . For a revised diagnosis and description refer to Ziegler, Sandberg \& Austin (1974).

\section{3.e. The Bispathodus ultimus Zone}

\section{Lower limit: FAD of Bispathdus ultimus}

\section{Upper limit: FAD of Protognathodus kockeli}

Remarks: The Bi. ultimus Zone is equivalent to the Upper expansa, Lower and Middle praesulcata zones of Ziegler \& Sandberg (1984), to the Middle and Upper costatus zones of Ziegler (1962) and to the Upper expansa and praesulcata zones and the costatus-kockeli Interregnum by Kaiser (2009). This zone extends for a quite long time frame compared to the adjacent zones in the uppermost Famennian strata, up to the Hangenberg Extinction Event. However, at present, there are no definite markers for a possible subdivision: the entry of Si. praesulcata was used for subdividing this inter-val, but this is not suitable due to the problems on the taxonomy of early siphonodellids. Protognathodus meischneri and Pr. collinsoni enter in the central part of this zone, but are rare and in many regions only documented above the Hangenberg Event (Corradini et al.
2011). Polygnathus purus and Po. symmetricus enter in the lower part of the Zone, but their first occurrence looks to be asynchronous worldwide.

The Bispathodus ultimus Zone can be roughly subdivided into two parts, the lower characterized by a more diverse fauna. In the central part of the zone, approximately in correspondence to the entry of protognathodids, conodonts actually experience a severe crisis marked by the extinction of several taxa $(\mathrm{Pa}$. perlobata, Pa. rugosa, Ps. m. marburgensis and Ps. brevipennatus) and several polygnathids became extinct. It is possible that a more precise zonation can be proposed after a complete revision of the early species of Siphonodella.

In the upper part of the Bi. ultimus Zone the Hangenberg extinction took place: according to Kaiser et al. (2009) up to $70 \%$ of conodont taxa disappeared in a short interval represented by the 'costatus-kockeli Interregnum'. However, uncertainties of contemporaneous extinctions among conodonts may result in problems of long-distance correlations. Also, this interval cannot be discriminated in places due to sedimentological features connected to the Hangenberg Event. However, where present it is a useful tool to discriminate the upper part of the Bi. ultimus Zone.

Notes on the index taxon: The species was erected by Bischoff (1957) who illustrated the holotype in plate 4, figure 24. The species was first revised by Zieg-ler, Sandberg \& Austin (1974), and later by Ziegler \& Sandberg (1984). In the latter paper the species was expanded to include Bi. ziegleri Rhodes et al. For a revised diagnosis and description refer to Ziegler \& Sandberg (1984).

\section{3.f. The Protognathodus kockeli Zone}

\section{Lower limit: FAD of Protognathodus kockeli}

\section{Upper limit: FAD of Siphonodella bransoni}

Remarks: The Pr. kockeli Zone is equivalent to the Upper praesulcata and sulcata zones of Ziegler \& Sandberg (1984) and to the kockeli and sulcata/kuehni zones of Kaiser et al. (2009).

and Melien, SW slope of Burg-Berg, Rhenish Slate Mountains. Refigured after Bischoff (1957, pl. 3, fig. 27a-b). (k) Protognathodus kockeli Bischoff, upper view. Plan di Zermula A section, Carnic Alps, sample PZA 2a1 of Perri \& Spalletta (2000b). (1) Protognathodus kockeli Bischoff, upper view. Plan di Zermula C section, Carnic Alps, sample PZC 4 of Perri \& Spalletta (2000b). (m) Protognathodus kockeli Bischoff, upper view. Passo di Monte Croce Carnico section, Carnic Alps, sample PMC 1. (n) Siphonodella bransoni Ji (= Siphonodella duplicata Morph 1 of Sandberg et al. 1978), upper (n1) and lower (n2) views. Element figured by Canis (1968, pl. 72, figs 22, 23) as Si. sulcata and indicated by Sandberg et al. (1978) as example of typical specimen of Si. duplicata Morph 1. (o) Siphonodella bransoni Ji (= Siphonodella duplicata Morph 1 of Sandberg et al. 1978). Hannibal Shale, $1.7 \mathrm{~m}$ above base, exposure on Grassy Creek, Cuivre Township, Pike County, Missouri (type Cuivre Shale Member). (p) Siphonodella bransoni Ji (= Siphonodella duplicata Morph 1 of Sandberg et al. 1978), upper (p1) and lower (p2) views. Woodford Shale, E110 at Ebey Dam, locality of Over (1992). (q) Siphonodella duplicata (Branson and Mehl) (=Siphonodella duplicata Morph 2 of Sandberg et al. 1978). Lectotype, upper (q1) and lower (q2) views. Bushberg Sandstone, exposure at Brickeys on the Mississippi River, Ste. Genevieve County, Missouri. Refigured after Klapper (in Ziegler, 1975). (r) Siphonodella duplicata (Branson and Mehl) (= Siphonodella duplicata Morph 2 of Sandberg et al. 1978), upper (r1) and lower (r2) views. Hannibal Shale, $1.7 \mathrm{~m}$ above base, exposure on Grassy Creek, Cuivre Township, Pike County, Missouri (type Cuivre Shale Member). (s) Siphonodella hassi Ji (= Siphonodella duplicata sensu Hass of Sandberg et al. 1978), upper (s1) and lower (s2) views. Woodford Shale, Hass G-1 locality of Over (1992). 
The marker Pr. kockeli is the only species that has its FAD just above the Hangenberg Event, and its validity for stratigraphic correlations is well known. Protognathodus kuehni, Ps. multistriatus and Po. purus subplanus enter in the lower part of the zone, more or less around the present DCB, but none is a good marker taxon.

Notes on the index taxon: The species was erected by Bischoff (1957) who illustrated the holotype in plate 4, figure 24. For a revised diagnosis and description refer to Corradini et al. (2011).

\section{3.g. The Siphonodella bransoni Zone}

Lower limit: FAD of Siphonodella bransoni $(=S i . d u-$ plicata M1)

Upper limit: FAD of Siphonodella duplicata $(=S i$. duplicata $\mathrm{M} 2$ )

Remarks: The Si. bransoni Zone was introduced by Ji (1985) and newly proposed by Kaiser et al. (2009). It is equivalent to the lower part of the Lower duplicata Zone of Sandberg et al. (1978).

Notes on the index taxon: The species was erected by $\mathrm{Ji}$ (1985), but a holotype was not indicated. The species is equivalent to Si. duplicata M1 sensu Sandberg et al. (1978), who referred to the specimen figured by Canis (1968, pl. 72, figs 22, 23) as a typical specimen. For a description of the taxon refer to the account of $\mathrm{Si}$. duplicata M1 by Sandberg et al. (1978). However, the designation of a type is needed, possibly reconsidering the collections by Canis (1968) mentioned by Sandberg et al. (1978) and/or Ji (1985).

\section{3.h. The Siphonodella duplicata Zone}

Lower limit: FAD of Siphonodella duplicata $(=S i . d u-$ plicata M2)

Upper limit: FAD of Siphonodella hassi $(=S i$. duplicata sensu Hass)

Remarks: This definition of the Si. duplicata Zone, here accepted, was introduced by Ji (1985) and newly proposed by Kaiser et al. (2009). It is equivalent to the upper part of the Lower duplicata Zone of Sandberg et al. (1978).

Notes on the index taxon: The species was erected by Branson \& Mehl (1934b), but a holotype was not indicated. Klapper (in Ziegler, 1975) choose a lectotype and illustrated it Siphonodella-plate 2, figure 6. For a description of the taxon refer to the account of $\mathrm{Si}$. $\mathrm{du}$ plicata M2 by Sandberg et al. (1978).

\section{Possible DCB position based on conodonts}

In order to redefine the Devonian-Carboniferous boundary, it is necessary to find a criterion that guaranties stability in the future and does not significantly change the present stratigraphic position. As stated in Section 2, the few conodont species that appear close to the present boundary do not have the characteristics of a stratigraphic index taxon since all are quite rare.

For the new definition of the boundary other fossil groups could be considered and checked for use as index fossils, but if the DCB working group decides to remain on conodonts there are two possible solu-tions: the FAD of Protognathodus kockeli and the FAD of Siphonodella bransoni. Both of these possible positions of DCB boundary have advantages and problems, briefly discussed in the following sections.

\section{4.a. FAD of Protognathodus kockeli}

Protognathodus kockeli is the most abundant and widely distributed species of Protognathodus and has long been used as an index taxon where the FAD is just above the Hangenberg Event but, as evidenced by Corradini et al. (2011), in many regions it only occurs above the present DCB. However, this can be related to the post-Hangenberg evolution of sedimentary basins that at places caused hiatuses above the Hangenberg shale equivalents (e.g. Sardinia: Corradini, Barca \& Spalletta, 2003; Mossoni, Corradini \& Spalletta, 2013; Mossoni et al. 2015).

Aretz (2014, p. 230) stated that placing the 'boundary at the Hangenberg level (biostratigraphically defined) offers the advantage that, in many cases, the DCB can be placed with sufficient accuracy without specific knowledge of the taxonomy of a specific fossil group'. The entry of Pr. kockeli respects this criterion, even if its local first occurrence is just above a facies break.

\section{4.b. FAD of Siphonodella bransoni}

Siphonodella bransoni (= Si. duplicata M1) is a wellknown, abundant and widely distributed species. The species is probably the best index taxon in the whole time frame around the DCB where the FAD is already used to define the base of the Si. bransoni Zone (= Lower duplicata Zone), which has long been considered the second zone of the Carboniferous. However, as pointed out by Aretz (2014), the FAD of Si. bransoni occurs well above the entry of Gattendorfia; it therefore does not respect the historical dimension of the boundary criterion, because Gattendorfia and other historically lowermost Carboniferous taxa would then become Devonian.

\section{4.c. Discussion of the new DCB criterion}

The new criterion for the definition of the DCB will be proposed by the working group and later voted on by the International Commission on Stratigraphy. In this article we can only give some advice.

If we consider the matter only from the view of conodont biostratigraphy, the FAD of Siphonodella bransoni would be the best choice: Si. bransoni is distributed 
worldwide and is quite easy to identify. However, the choice of Si. bransoni as criterion for the DCB would create problems regarding the historical position of the boundary; if the FAD of Si. bransoni was chosen, the historical first part of the Carboniferous system will be included in the Devonian system.

The FAD of Protognathodus kockeli corresponds more or less, or is exactly equivalent, to the historical Devonian-Carboniferous boundary, much better than the supposed FAD of Si. sulcata. It enters just above the Hangenberg Event, which is recognizable around the world in most marine strata and is a more natura boundary (Walliser, 1985) between the two systems.

A boundary placed just after the Hangenberg Event has the advantage that it will be possible to indicate an approximate position of DCB even in sections where Pr. kockeli is not present. We therefore support this criterion as preferable.

\section{Conclusion}

Recent studies show that a different level should be used to define the DC boundary. Rarity of some important stratigraphic guides in the uppermost Famennian strata and close to the DCB, as well as inconsistency in the taxonomic concept of early siphonodellids, compel us to propose a new zonation scheme for this stratigraphic interval.

The distribution of the most important conodont species have been investigated in order to evaluate their stratigraphic potential for a revised zonation of the uppermost Famennian and lowermost Tournaisian strata and for the redefinition of the Devonian-Carboniferous boundary. In this stratigraphic interval only a few conodont taxa meet the requirements of global index taxa: easy to recognize, a well-documented stratigraphic range and a broad geographic distribution. Some species of Bispathodus are good markers in the uppermost Famennian strata. Among Protognathodus only Pr. kockeli could be used, while the other representatives of the genus have a very low stratigraphic potential due to their rarity. Species of Siphonodella in the Tournaisian part of the range of the genus, the entry of Si. bransoni and above, may be very good markers, but it is better to avoid the use of the early representatives because of significant taxonomic uncertainties in the identification of Si. sulcata from the supposed ancestor Si. praesulcata.

The proposed revised part of the conodont scheme comprises seven zones. In ascending order, these are: Bispathodus aculeatus Zone; Bispathodus costatus Zone; Bispathodus ultimus Zone; Protognathodus kockeli Zone; Siphonodella bransoni Zone; Siphonodella duplicata Zone; and Siphonodella hassi Zone. The bases of these zones are defined by FADs of conodont species of the nominative taxa.

As for the new definition of the DCB, we propose the FAD of Si. bransoni or the FAD of Pr. kockeli. The latter is preferable, because it is very close to the historical position of the base of the Carboniferous system and, placed just above the Hangenberg Event, has the advantage that it can be recognized in localities where the taxon is not present.

Acknowledgements. This study was partly supported by RAS (grants LR7/07 - 2010, resp. C. Corradini). This study is a contribution to PGI-NRI Project 61.2908.1304.00.0 (HM). We acknowledge the useful comments, corrections and suggestions by Jed Day and an anonymous reviewer. This paper is a contribution to IGCP 596 'Mid Palaeozoic climate and biodiversity'.

\section{References}

ARETZ, M. 2014. Redefining the Devonian-Carboniferous Boundary: an overview of problems and possible solutions. In Strati 2013 (eds R. Rocha, J. Pais, J. C. Kullberg, S. Finney), pp. 227-31. Switzerland: Springer.

BAHRAMI, A., CORRADINI, C. \& YAZDI, M. 2011. Conodont biostratigraphy across the Devonian-Carboniferous boundary in the Shotori Range, Tabas area, central east Iran Microplate. Bollettino della Società Paleontologica Italiana 50, 35-53.

BARskov, I. S., Vorontsova, T. N., KonOnOVA, L. I. \& KuZMIN, A. V. 1991. Index conodonts of the Devonian and Early Carboniferous. Moskow: Moskow University, $183 \mathrm{pp}$.

BECKER, R. T. 2012. The uncounted species of Polygnathus - Plea for clear tracks through a taxonomic jungle. $S D S$ Newsletter 27, 42-8.

BECKER, R. T. 2013. Species list of Polygnathus - corrections and addictions. SDS Newsletter 28, 29-31.

Becker, R. T., Gradstein, F. M. \& Hammer, O. 2012. The Devonian Period. In The Geologic Time Scale 2012 (eds F. M. Gradstein, J. G. Ogg, M. Schmitz \& G. Ogg), pp. 559-601. Oxford: Elsevier.

Becker, R. T., Hartenfels, S., Aboussalam, Z. S., Tragelehn, H., Brice, D. \& El Hassani, A. 2013. The Devonian-Carboniferous boundary at Lalla Mimouna (Northern Maider) - A progress report. In International Field Symposium 'The Devonian and Lower Carboniferous of northern Gondwana' - Field Guidebook (eds R. T. Becker, A. El Hassani \& A. Tahiri), pp. 109-20. Document de l'Institut Scientifique, Rabat 27.

BischofF, G. 1957. Die Conodonten-Stratigraphie des rhenoherzynischen Unterkarbons mit Berücksichtigung der Wocklumeria-Stufe und der Devon/KarbonGrenze. Abhandlungen hessisches Landesamt für Bodenforschung 19, 1-64.

Branson, E. B. 1934. Conodonts from the Hannibal Formation of Missouri. Missouri University Studies 8, 301-43.

Branson, E. B. \& MeHL, M. G. 1934a. Conodonts from the Grassy Creek shale of Missouri. Missouri University Studies 8, 171-259.

Branson, E. B. \& Mehl, M. G. 1934b. Conodonts from the Bushberg sandstone and equivalent formations of Missouri. Missouri University Studies 4, 265-300.

CANIS, W. F. 1968. Conodonts and biostratigraphy of the Lower Mississippian of Missouri. Journal of Paleonto$\log y$ 42, 525-55.

CAsier, J.-G., Lethiers, F. \& PrÉAT, A. 2002. Ostracods and sedimentology of the Devonian-Carboniferous stratotype section (La Serre, Montagne Noire, France). Bulletin de l'Institut Royal des Sciences Naturelles de Belgique, Science de la Terre 72, 43-68. 
CoRRADINI, C. 2003. Late Devonian (Famennian) conodonts from the Corona Mizziu sections near Villasalto (Sardinia, Italy). Palaeontographia Italica 98, 65-116.

CORRADINI, C. 2008. Revision of Famennian-Tournaisian (Late Devonian-Early Carboniferous) conodont biostratigraphy of Sardinia, Italy. Revue de Micropaleontologie 51, 123-32.

Corradini, C., Barca, S. \& Spalletta, C. 2003. Late Devonian-Early Carboniferous conodonts from the "Clymeniae limestones" of SE Sardinia (Italy). Courier Forschungs-Institut Senckenberg 245, 227-53.

Corradini, C., Kaiser, S. I., Perri, M. C. \& SPalletta, C. 2011. Protognathodus (Conodonta) and its potential as a tool for defining the Devonian/Carboniferous boundary. Rivista Italiana di Paleontologia e Stratigrafia 117, 1528.

DAVYdov, V. I., KoRn, D. \& SchMitz, M. D. 2012. The Carboniferous Period. In The Geologic Time Scale 2012 (eds F. M. Gradstein, J. G. Ogg, M. Schmitz \& G. Ogg), pp. 603-649. Oxford: Elsevier.

Evans, S. D., Over, D. J., Day, J. E. \& Hasenmueller, N. R. 2013. The Devonian/Carboniferous boundary and the holotype of Siphonodella sulcata (Huddle, 1934) in the upper New Albany Shale, Illinois Basin, southern Indiana. In International Field Symposium 'The Devonian and Lower Carboniferous of northern Gondwana' - Field Guidebook (eds A. El Hassani, R. T. Becker, A. Tahiri), pp. 42-3. Document de l'Institut Scientifique, Rabat 26.

FLAJS, G. \& FEIST, R. 1988. Index conodonts, trilobites and environment of the Devonian-Carboniferous boundary beds at La Serre (Montagne Noire, France). Courier Forschungs-Institut Senckenberg 100, 53-107.

GATOvsky, Y. A. 2009. New Genera Barskovella and Bizignathus (Conodonts) from the Famennian of Southern Kazakhstan. Paleontological Journal 43, 550-7.

Girard, C., Cornée, J.-J., Corradini, C., Fravalo, A. \& FEIST, R. 2014. Paleoenvironmental changes at Col des Tribes (Montagne Noire, France), a reference section for the Famennian of north Gondwana-related areas. Geological Magazine 151, 864-84.

HARTENFELS, S. 2011. Die globalen Annulata-Events und die Dasberg-Krise (Famennium, Oberdevon) in Europa und Nord-Afrika: hochauflösende ConodontenStratigraphie, Karbonat-Mikrofazies, Paläoökologie und Paläodiversität. Münstersche Forschungen zur Geologie und Paläontologie 105, 17-527.

Hou, H. F., JI, Q., WU, X. H., XIONG, J., WANG, S., GAO, L., SHENG, H., WIE, J. \& TURNER, S. 1985. Muhua Section of Devonian-Carboniferous Boundary Beds. Geological Publishing House, Beijing, China, $226 \mathrm{pp}$.

JI, Q. 1985. Study on the phylogeny, taxonomy, zonation and biofacies of Siphonodella (Conodonta). Bulletin of the Institute of Geology 11, 51-75.

JI, Q. 1987. New results from Devonian-Carboniferous boundary beds in South China. Newsletters on Stratigraphy 17, 155-67.

JI, Q. \& ZIEGLER, W. 1992. Phylogeny, speciation and Zonation of Siphonodella of shallow water facies (Conodonta, Early Carboniferous). Courier ForschungsInstitut Senckenberg 154, 149-77.

JI, Q. \& ZIEGLER, W. 1993. The Lali section: an excellent reference section for Late Devonian in south China. Courier Forschungsinstitut Senckenberg 157, 1-183.

KAISER, S. I. 2009. The Devonian/Carboniferous stratotype section La Serre (Montagne Noire) revisited. Newsletters on Stratigraphy 43, 195-205.
Kaiser, S. I., Becker, R. T., SPAlletta, C. \& Steuber, T. 2009. High-resolution conodont stratigraphy, biofacies and extinctions around the Hangenberg Event in pelagic successions from Austria, Italy and France. Palaeontographica Americana 63, 97-139.

KAISER, S. I. \& CORRADINI, C. 2011. The early Siphonodellids (Conodonta, Late Devonian-Early Carboniferous): overview and taxonomic state. Neues Jahrbuch für Geologie und Paläontologie Abhandlungen 261, 19-35.

KalvODA, J., KumPAN, T. \& BABEK, O. 2015. Upper Famennian and Lower Tournaisian sections of the Moravian Karst (Moravo-Silesian Zone, Czech Republic): a proposed key area for correlation of the conodont and foraminiferal zonations. Geological Journal 50, 17-38.

KlapPer, G. \& Foster, C. T., JR. 1993. Shape analysis of Frasnian species on the Late Devonian conodont Genus Palmatolepis. Paleontological Society Memoir 32, 1-35.

Komatsu, T., Kato, S., Hirata, K., TaKashima, R. Ogata, Y., OBA, M., NARUSE, H., TA, P. H., NGUYen, P. D., Dang, H. T., DOAN, T. N., NGUYen, H. H., SAKata, S., Kaiho, K. \& KÖNIGShoF, P. 2014. Devonian-Carboniferous transition containing a Hangenberg Black Shale equivalent in the Pho Han Formation on Cat Ba Island, northeastern Vietnam. Palaeogeography, Palaeoclimatology, Palaeoecology 404, 30-43.

KonONOVA, L. I. \& WeYER, D. 2013. Upper Famennian conodonts from the Breternitz Member (Upper Clymeniid Beds) of the Saalfeld region, Thuringia (Germany). Freiberger Forschungshefte C 545, 15-97.

Kumpan, T., BABEK, O., KALVODA, J., FrYDA, J. \& GRYGAR, T. M. 2014a. A high-resolution, multiproxy stratigraphic analysis of the Devonian-Carboniferous boundary sections in the Moravian Karst (Czech Republic) and a correlation with the Carnic Alps (Austria). Geological Magazine 151, 201-15.

Kumpan, T., BABEK, O., Kalvoda, J., Grygar, T. M. \& FRYDA, J. 2014b. Sea-level and environmental changes around the Devonian-Carboniferous boundary in the Namur-Dinant Basin (S Belgium, NE France): A multiproxy stratigraphic analysis of carbonate ramp archives and its use in regional and interregional correlations. Sedimentary Geology 311, 43-59.

LANE, H. R., SANDBerg, C. A. \& Ziegler, W. 1980. Taxonomy and phylogeny of some Lower Carboniferous conodonts and preliminary standard post-Siphonodella zonation. Geologica et Palaeontologica 14, 117-64.

MALEC, J. 2014. The Devonian/Carboniferous boundary in the Holy Cross Mountains (Poland). Geological Quarterly 58, 217-34.

MATYja, H., SOBIEN, K., MARYNOWSKi, L., StempienSAŁEK, M. \& MAŁKOWSKI, K. 2015. The expression of the Hangenberg Event (latest Devonian) in a relatively shallow-marine succession (Pomeranian Basin, Poland): the results of a multi-proxy investigation. Geological Magazine 152, 400-28.

Mossoni, A., Carta, N., Corradini, C. \& Spalletta, C. 2015. Conodonts across the Devonian/Carboniferous boundary in SE Sardinia (Italy). Bulletin of Geosciences 90, 371-88.

Mossoni, A., Corradini, C. \& Spalletta, C. 2013. Conodonts from the Monte Taccu section (FamennianTournaisian, Sardinia, Italy). Asociación Paleontológica Argentina, Publicación Especial 13, 85-90.

Over, D. J. 1992. Conodonts and the DevonianCarboniferous boundary in the Upper Woodford Shale, Arbuckle Mountains, South-Central Oklahoma. Journal of Paleontology 66, 293-311. 
Paproth, E., Feist, R. \& Flajs, G. 1991. Decision on the Devonian-Carboniferous boundary stratotype. Episodes 14, 331-6.

PerRi, M. C. \& SPALlettA, C. 1991. Famennian conodonts from Cava Cantoniera and Malpasso sections, Carnic Alps, Italy. Bollettino della Società Paleontologica Italiana 30, 47-78.

Perri, M. C. \& Spalletta, C. 2000a. Devonian-Early Carboniferous transgressions and regressions in the Carnic Alps (Italy). Record of the Western Australian Museum 58(Suppl), 305-19.

Perri, M. C. \& Spalletta, C. 2001b. Hangenberg Event al limite Devoniano/Carbonifero al Monte Zermula, Alpi Carniche, Italia. Giornale di Geologia, ser. $3^{\circ}$ 62(Suppl), 31-40.

QIE, W., ZhANG, X., DU, Y., YANG, B., JI, W. \& LUO, G. 2014. Conodont biostratigraphy of Tournaisian shallow water carbonates in central Guangxi, South China. Geobios 47, 389-401.

QIe, W., Wang, X., Zhang, X., Ji, W., Grossman, E.L., HuAnG, X, LiU, J. \& LuO, G. 2015. Latest Devonian to earliest Carboniferous conodont and carbon isotope stratigraphy of a shallow-water sequence in South China. Geological Journal, published online 11 August 2015, doi: 10.1002/gj.2710.

SANDBERG, C. A. \& KlAPPER, G. 1967. Stratigraphy, age, and paleotectonic significance of the Cottonwood Canyon Member of the Madison Limestone in Wyoming and Montana. United States Geological Survey Bulletin 1251-B, 1-70.

SANDBERG, C. A., Streel, M. \& SCOTt, R. A. 1972. Comparison between conodont zonation and spore assemblages in the Devonian-Carboniferous boundary in the western and central United States and in Europe. In $\mathrm{Se}$ ptième Congrès Internationale de Stratigraphie Géologie di Carbonifère, Krefeld, 23-28 August 1971, Compte Rendu 1, 179-203.

SANDBERG, C. A. \& ZiegLeR, W. 1996. Devonian conodont biochronology in geologic time calibration. Senckenbergiana Lethaea 76, 259-65.

SANDBERG, C. A., ZIEGLER, W., LeUteritZ, K. \& Brill, S. M. 1978. Phylogeny, speciation and zonation of Siphonodella (Conodonta, Upper Devonian and Lower Carboniferous). Newsletters on Stratigraphy 7, 102-20.

SANZ LóPEZ, J., Garcìa LóPeZ, S., Montesinos, J. R. \& ARBIZU, M. 1999. Biostratigraphy and sedimentation of the Vidrieros Formation (middle Famennianlower Tournaisian) in the Gildar-Montó unit (nortwest Spain). Bollettino della Società Paleontologica Italiana 37, 393-406.

VOGES, A. 1959. Conodonten aus dem Unterkarbon I and II (Gattendorfia und Pericyclus-Stufe) des Sauerlandes. Paläontologische Zeitschrift 3, 266-314.
Voges, A. 1960. Die Bedeutung der Conodonten für die Stratigraphie des Unterkarbon I and II (Gattendorfiaund Pericyclus-Stufe) im Sauerland. Fortschritte in der Geologie von Rheinland und Westfalen 3, 197-228.

Vorontsova, T N. 1993. The genus Polygnathus sensu latu (Conodonta): phylogeny and systematics. Palaeontological Journal 27, 83-99.

WALLISER, O. H. 1985. Natural boundaries and commission boundaries in the Devonian. Courier Forshungs-Institut Senckenberg 75, 401-7.

WANG, C. Y. \& YIN, B. A. 1984. Conodont zonations of early Lower Carboniferous and DevonianCarboniferous boundary in pelagic facies, South China. Acta Palaeontologica Sinica 23, 224-38.

WANG, C. Y. \& YIN, B. A. 1988. Conodonts. In DevonianCarboniferous Boundary in Nanbiancun Guilin (ed. C. M. Yu), pp. 105-48. Beijing: Science Press.

ZIEGLER, W. 1962. Taxionomie und Phylogenie Oberdevonischer Conodonten und ihre stratigraphische Bedeutung. Abhandlunghen des Hessisches Landesamt für Bodenforschung 38, 1-166.

ZIEGLER, W. 1969. Eine neue Conodontenfauna aus dem höchsten Oberdevon. Fortschritte Geologie von Rheinland und Westfalen 17, 179-91.

ZIEGLER, W. 1971. Conodont stratigraphy of the European Devonian. Geological Society of America Memoirs 127, 67-99.

ZIEGLER, W. (ed.) 1975. Catalogue of Conodonts, 3. Schweizerbart'sche Verlagsbuchhandlung, Stuttgart, 404 $\mathrm{pp}$

ZIEGLER, W. 1979. Historical subdivisions of the Devonian. Special Papers in Paleontology 23, 23-47.

ZIEGLER, W. (ed.) 1981. Catalogue of Conodonts, 4. Schweizerbart'sche Verlagsbuchhandlung, Stuttgart, 445 pp.

ZIEGLER, W. \& SANDBERG, C. A. 1984. Palmatolepis-based revision of upper part of standard Late Devonian conodont zonation. Geological Society of America Special Paper 196, 179-94.

ZIEGLER, W. \& SAndBerg, C. A. 1990. The Late Devonian Standard Conodont Zonation. Courier ForschungsInstitut Senckenberg 121, 1-115.

ZIEGLER, W. \& SANDBERG, C. A. 1994. Conodont phylogenetic-Zone concept. Newsletters on Stratigraphy 30, 105-23.

ZIEGLER, W. \& SANDBERG, C. A. 1996. Reflexions on Frasnian and Famennian Stage boundary decisions as a guide to future deliberations. Newsletters on Stratigraphy 33, 157-80.

Ziegler, W., SANDBerg, C. A. \& Austin, R. L. 1974. Revision of Bispathodus group (Conodonta) in the Upper Devonian and Lower Carboniferous. Geologica et $\mathrm{Pa}$ laeontologica 8, 97-112. 